\title{
A CORRELATION ANALYSIS OF EDUCATION FOR SUSTAINABLE DEVELOPMENT IN PRE AND POST COVID SCENARIOS
}

\author{
Juan Franquelo Soler ${ }^{1+}$ \\ E. Beatriz Blazquez- \\ Parra $^{2}$
}

\author{
${ }_{1,2}^{10}$ University of Malaga, Spain. \\ 'Email:ifranquelo@uma.es Tel: +34-629099291 \\ Email: ebeatriz@uma.es Tel:+34-952952136512
}

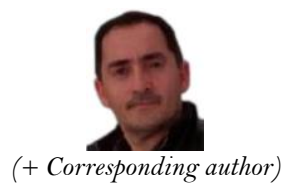

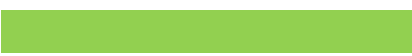

\section{Article History}

Received: 7 September 2021 Revised: 2 December 2021

Accepted: 20 December 2021 Published: 4 January 2022

\section{Keywords}

Confinemen

COVID19

Development

Education

Environment

Sustainable development.
Education for sustainable development (ESD) has become a focus of international education attention, for its multidisciplinary character and for the interest in caring for the environment due to their degradation and environmental impact. This study compared two tests, one was conducted before confinement on 325 participants with 3545 responses, and one in confinement on 350 participants with 3832 responses. Surveys were conducted using Google Forms, based on 11 questions with its items verified by ANOVA and Bonferroni. The COVID-19 lockdown significantly influenced the results of both tests. The results indicated increased awareness of the environment during confinement. At the educational level it was intended to take an initial test and a year later perform a second test to compare them. The first test was carried out online at school, and the second one was held a year later in confinement due to COVID-19. This unexpected circumstance became an opportunity to value and compare them in different circumstances. Surveys were conducted using Google Forms. The results indicated a more significant concern for sustainability. The conclusion has been that students behave more sensitively to sustainable development in confinement circumstances.

Contribution/Originality: The paper's primary contribution is finding that there is a greater sensitivity in students regarding the care of the environment within the circumstances of confinement due to COVID-19. This study compared two tests, one was conducted before confinement on 325 participants with 3545 responses, and one in confinement on 350 participants with 3832 responses.

\section{INTRODUCTION}

Sustainable development from education, as a common good, and by its diversity, has become an educational driving axis induced by environmental deterioration and concerns of citizens and politics (UNESCO, 2018). As a result, related activities have increased in schools at all levels around the world. De Pauw, Gericke, Olsson, and Berglund (2015) mention the effectiveness of Education for Sustainable Development (ESD) in Sweden. The interdisciplinarian factor in postgraduate students of MBA is studied by Annan-Diab and Molinari (2017) while its application and reception in university centers in Belgium is mentioned by Verhulst and Lambrechts (2015). The advancement in e-learning in Portugal is studied by Azeiteiro, Bacelar-Nicolau, Caetano, and Caeiro (2015). These are a few examples of case studies in line with the subject of this study. An example of related activities arose in 2019 in a secondary education center in Malaga (Spain) located in the center of the city, where a team of teachers 
was created with the aim of reducing and improving energy consumption and knowing the educational response of students as well as their interrelationship (Tucker and Izadpanahi, 2017; Izadpanahi, Elkadi, and Tucker 2017).

The initial idea was to conduct technical and educational control (Ozburak, Batırbaygil, and Uzunoglu,2018; Phan, Thu, and Kato2016). At the technical level, it was intended to know the electricity consumption and its evolution and to carry out a series of actions such as reforms and facilities (Saraiva, Almeida, Bragança, and Barbosa,2019); the modes of educational interaction (Meron and Meir,2017); Mirchandani (2015). A few other actions included installation of photovoltaic solar panels on the center cover; replacement of energy-efficient illuminations, improvement of the power factor for electrical installation; control and improvement of the installation of plumbing and its consumer appliances with appropriate closures; and replacement of exterior windows with double glazing windows (Ashrafian and Moazzen, 2019). Additionally, other actions that deserve mention are creation of a vertical garden as a green facade in the center representing aesthetics and freshness, and building a particularly warm area (McCullough, Martin, and Sajady (2018); Iyengar (2015). In terms of empirical studies, De Pauw, Gericke, Olsson, and Berglund (2015) determined the difference between the holistic and pluralistic aspects of ESD over the effectiveness of Education for Sustainable Development, and Annan-Diab and Molinari (2017) indicated how to advance interdisciplinary education for sustainable development. Other empirical studies focused on the importance of human factors in a ESD change process, Verhulst and Lambrechts (2015).

To carry out this study, a few actions like photovoltaic installation with 38 plates, the replacement of luminaires, and the start of the vertical garden were planned and implemented. This was accomplished at the educational level by carrying out an initial test and a year later a second test to make a comparison This was in line with Prabawani, Hanika, Pradhanawati, and Budiatmo(2017). This test of 11 questions was consensual and proposed by a group of teachers from the educational center trying to collect most of the concepts of the ESD and trying to preserve its simplicity and comfort. The first test was performed at the center and the second was held a year later online in confinement due to COVID19. The second test consisted of the same questions as the first one but after a duration of one year. The unexpected circumstance of confinement due to the pandemic had given an opportunity to assess and compare both surveys in very different circumstances.

The current study made a comparative examination of both the tests across all educational levels. A study of each question was also carried out by comparing the results of both years. The ANOVA was also carried out to find out whether confinement resulted in a greater sensitivity or concern for environmental care and sustainable development.

In future a third test may be carried out on similar lines but it is not sure what the results would be. It is also difficult to say whether the third test will be face-to-face or online or in blended form. However, it would be possible to observe the evolution before, during and after the third test to check whether the increase in sensitivity was transient due to the confinement, as suggested by the media, or whether it was actually the sensitivity residing in students.

\section{METHODOLOGY}

As said earlier, the first test was carried out in 2019 in a computer room enabled for this purpose. To complete the test, students had to enter through a prepared link and answer 11 questions. The following year in 2020, after a gap of one year, they were required to carry out the same test but remotely, either from home or in confinement due to COVID19. The Test 1 was participated by 325 participants, obtaining 319 answers from question no. 1, 324 from 2, 322 from 3, 323 from 4, 324 from 5, 323 from 6, 321 from 7, 319 from 8, 323 from 9, 324 from 10 and 323 from question no. 11. The test was satisfactorily validated by a high number of responses within the population with 3545 responses over 3575 possible, representing $99.16 \%$.

A year later, the test 2 was conducted on 350 participants to get 349 answers from question no. 1, 350 from 2 , 345 from 3, 349 from 4, 350 from 5, 349 from 6, 344 from 7, 347 from 8, 350 from 9, 349 from 10 and 350 from 
question no. 11. Test 2 was also considered validated with 3832 responses over 3850 possible, representing $99.53 \%$. When the two tests were compared, we observed that 321 was the lowest number of answers within test 1 while it was 344 for test 2 , which is why we chose the first 321 questions of both tests for correlation study. Both the tests were consensual and proposed by a group of teachers from the educational center trying to collect maximum concepts of ESD and preserving its simplicity and comfort. Each test had a total of 11 questions. The respondents in each test were required to indicate their course, gender and age prior to start the questionnaire in the Google Forms.

Focusing the subject of education for sustainable development according to UNESCO standards, the first question was: What is sustainable development? The response options were: (a) The Model or Ideal of the United Nations; b) Development that meets current needs without compromising the ability of future generations to meet their own needs; c) Both A and B. This question sought to direct students' thinking to the goal or paradigm of the United Nations and its concept as mentioned by Willis (2018) and United Nations (2018).

The second question aimed at entering a personal area and a little further from formalism, and to know the extent of involvement of students and their relationship with the environment. It stated: Do you take care of the environment? The response options were measured on a 10-point scale, with 1 denoting 'No' or very minimum level to 10, denoting 'I take good care of environment' or of maximum level. This question sought to know the attitude of students towards the care of the environment seen from them. This is consistent with Reunamo and Suomela (2013) in their acting guide and with Perello-Marín, Ribes-Giner, and Pantoja Díaz (2018) in the university field.

The third question gave importance to the concept of sustainability and stated: "Among the principles of sustainable development are........" The choices were: a) Human beings have the right to a healthy and productive life in harmony with nature; (b) The right to development should be exercised in such a way as not to respond equitably to the environmental and development needs of current and future generations; c) Both A and B are false. This question aimed at finding the value of knowledge about the concept of sustainable development. Its purpose was to measure the attention level or good knowledge about sustainable development. This type of measurement of implementation and development has also been studied by Disterheft, Caeiro, Azeiteiro, and Leal (2013).

Recycling has proved a very important pillar in the care of the environment. Hence, the fourth question was in colloquial language: "Packaging/metal/plastic what container would you throw it into?" The response options were: a) Green; b) Grey; c) Blue; d) Yellow. This question provides us with valuable information about recycling. A good study was carried out on recycling in the education curriculum in Istanbul's primary schools (Gönüllü, Doğan, and Çelik,2015).

Going back to the theoretical concepts, about energy sources, the fifth question stated: "Which natural resource you think is renewable?" The response options were: a) Wind b) Wood c) Oil d) Paper (e) Water f) Natural gas g) Sun h) Coal. This question aimed at collecting the information about the knowledge of renewable energy sources from the perspective of adolescents (Keramitsoglou,2016; Cheong, Johari, Said, and Treagust,2015).

In order to know personal behavior regarding the impact of their habits on the environment, the sixth question stated: "On the scale of 1 to 10, how much do you think your everyday consumption habits (food, clothing, footwear) contribute to climate change?" The response options were measured on a 10-point scale with 1 being 'nothing' or of minimum value and 10 to mean "a lot', with the maximum value. This question sought to know what perception students had about the impact of their habits. Wals (2012) developed this concept from UNESCO (2018) and Gardner (2017) focused on teenagers while Kane (2011) studied its emotional aspect.

The seventh question aimed at capturing the attention of the students in the green project of the center. This implied an aesthetic change and practical involvement at the level of workshops and teamwork in the construction and design of the green façade. The question stated "How do the vertical gardens contribute to sustainability?" The response options were: a) They do not promote nature or aesthetics in urban environments; b) They create a natural insulator that partly regulates the temperature of buildings; c) Both A and B are correct. This question aimed to 
assess the students' knowledge about green facades and their different functions, in a greener field while still constituting an aesthetic and energy improvement, or as an opportunity for social transformation (Santos, Singh, Delgado Leandro da Cruz, De Carvalho Piassi, and Reis,2019).

The importance of reducing environmental impact was at the heart of the eighth question: "What is important to reduce the environmental impact?" The answer choices were: a) Moving on foot, by bike or using public transport, recycling, and reuse; b) The use of disposable plastic materials as they are very biodegradable; c) The use of type $\mathrm{E}, \mathrm{F}$ or $\mathrm{G}$ appliances better than $\mathrm{A}+++$ or $\mathrm{A}++$. This question aimed at providing information on knowledge and the need to reduce environmental impact from different approaches such as transport, material types and efficient energy consumption. Reconnection with nature can be an important element of awareness as pointed out by Braun and Dierkes (2017), or participation in eco-schools is essential for ESD as mentioned by Boeve-de Pauw and Van Petegem (2018).

Stressing the importance of recycling and its new types, the ninth question stated: "What are your views about Electronic waste (equipment, batteries, etc.)?” The answer choices were: a) It is a false concept because there is no electronic garbage; b) Electronic waste has decreased over the past few years; c) It must be recycled, especially batteries in specific tanks. This question aimed to capture students' attention to the concept of electronic garbage and its recycling, as studied by Pérez-Belis, Bovea, and Simó (2015) focusing on consumption habits and their relationship to environmental education. A case study was also carried out in Spain on electronic toys or introduction of Electronic waste in the curriculum in primary schools(De Jager,2015).

With the aim of knowing the interest in green initiatives and projects at personal level, the tenth question stated: "On the scale of 1 to 10 , would you like to participate in a project or activity related to such environmental issues?" The response options on a 10-point scale ranged from 1 denoting nothing or minimum value and 10 meaning a lot or the maximum value. This question sought to know the degree of involvement of students in projects related to the care of the environment. Clark (2010) went further and involved the educational community, as challenges and benefits in Germany were studied by Carbach and Fischer (2017).

In the vicinity of the educational center there is a large green project, in order to assess the knowledge and interest in it. The eleventh and final question stated: "In your neighborhood there is a project to build a green lung (urban forest of Malaga). Do you know this initiative?" The answer options were just 'Yes' or 'No'. This question sought to find out how many knew about a large project very close to the educational center and their homes. This was one of the largest parks in the city with an extensive green area called the urban forest of Malaga. People in in the city ought to expect a lot of environmental sustainability due to this park situated in one of the densest areas of Europe and with fewer green areas in the vicinity.

The involvement of students in decision-making needs to be more than desirable from sustainable development to solidarity development beyond urban speculation(Gaona,2000), and deriving benefit from interaction with external actors to the educational center (Cooke,2010). These questions have easily addressed the most important aspects of sustainable development, and enabled a question-to-question global comparison. These questions were adapted from a study by Hedefalk, Almqvist, and Östman (2015).

The findings of the study comprised valuable information confirmed by ANOVA methods. The results can be presented to students in order to establish a dialogue and clarify the lines of work as suggested by Haddad and Kalaani (2014). The ANOVA method has already been used in sustainability studies in secondary education centers (Rozema, Mathijssen, Jansen, and Van Oers,2018; Jena, Bhattacharjee, and Langthasa,(2015). 


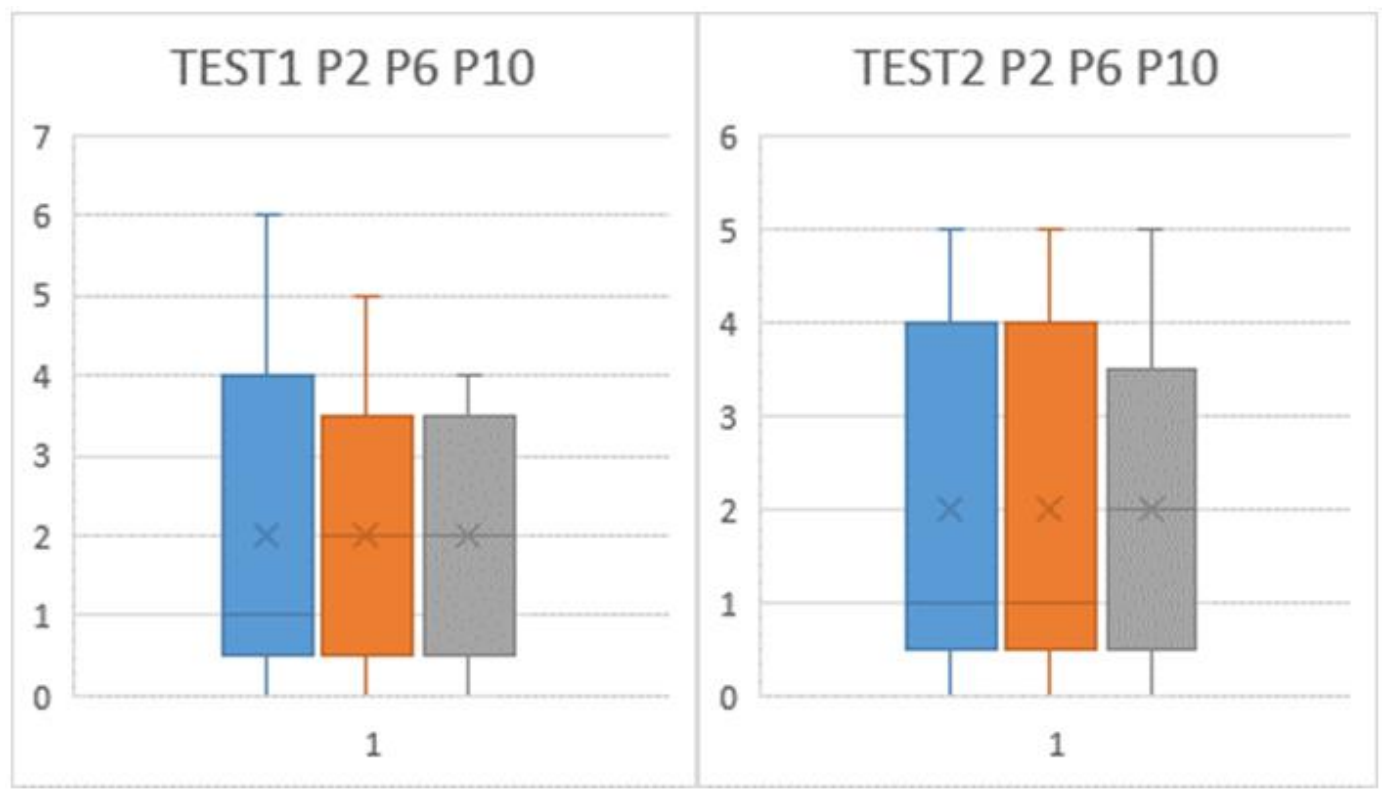

Figure 1. Proactive question box charts.

A two-factor ANOVA method was performed on several individuals per group by question blocks. The personal and proactive question block kept one factor for each block in order to know the variation of questions regarding the confinement situation. The first block was defined as conceptual question, the second as proactive question, and the third as procedural question. To confirm the results, Bonferroni application was applied by pairs of questions, with mostly satisfactory results. The normality of the samples was also confirmed with studies of deviation and Kurtosis among others. Figure 1 and 2 present the box charts of the procedural questions, observing Levene's homoscedasticity and associated normality.

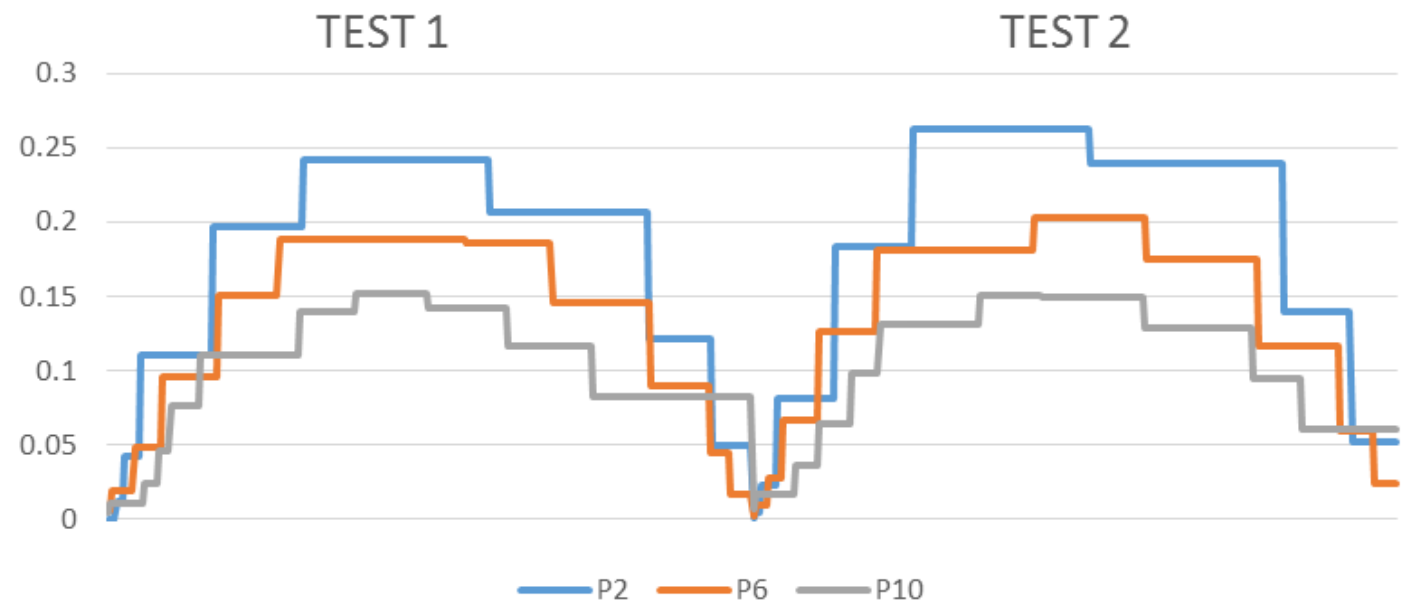

Figure 2. Normality graphs of proactive questions.

\section{RESULTS}

The first test was carried out in the spring of 2019 in the school itself, in a computer room enabled for this purpose with a total of 325 participants, comprising $41.8 \%$ female and $58.2 \%$ male. A majority of participation was in compulsory secondary education, group C (3 ESO C) with $8.3 \%$ and 3 ESO B with $7.1 \%$. The second test was carried out in the spring of 2020 from home, in confinement due to COVID with a total of 350 participants, comprising $49.4 \%$ female and $50.6 \%$ male. A majority of participation was in compulsory secondary education in ESO 3rd courses with $10.3 \%$, 4 ESO C with $8.9 \%$ and 3 ESO C with $6.3 \%$. 
The most conceptual questions were 1,3,5 and 7 and showed the following results: on the definition of sustainable development $35.7 \%$ were right in Test 1 ; and $34.1 \%$ in Test 2. The erroneous responses were also significantly similar. On the principles of sustainable development, healthy living, sustainability, and environmental needs, $51.6 \%$ were right in Test 1 , and $53.9 \%$ in Test.2. The wrong answers were also significantly similar. On renewable natural resources, $95.4 \%$ were hit wrong in Test 1 , and $94.1 \%$ in Test 2 . The wrong answers were also significantly similar, viz., in Test 1 the wrong ones were: oil 2.5\%; GN (Natural Gas) $1.2 \%$; $0.9 \%$; while in Test 2, oil $2 \%$, GN 4\%, coal $0.6 \%$. Most of them indicated the 'sun' and 'wind' as renewable natural sources; however, in Test 2 , there was a greater diversification within the correct options.

On the concept of vertical gardens, ecological promotion, urban aesthetics, and natural insulation found involvement of $60.1 \%$ students in Test 1 and $70.9 \%$ in Test 2. A significant improvement was observed in Test 2. The answers to the conceptual questions were similar in both tests, however, a greater knowledge of renewable energies was highlighted by the diversity of responses and a significant improvement $(+10.8 \%)$ was observed in the knowledge of green facades in Test 2. The most proactive and personal questions were 2, 6, and 10, which showed the following results: "on the care of the environment" in Test 1 (indications 0 to 4 on the scale of 0 to 10 ), $4.6 \%$ stated that they took little care $; 40.8 \%$ stated they were very careful (indications 8 to 10 on the scale of 0 to 10 ), $54.6 \%$ were found on the acceptable scale (indications 5 to 7 on the scale of 0 to 10 ).

In Test 2, 3.8\% indicated that they did not take care (indications 0 to 4 on the scale of 0 to 10 ), while $48.3 \%$ stated that they were very careful (indications 8 to 10 on the scale of 0 to 10 ), while $48.1 \%$ were on the acceptable scale (indications 5 to 7 on the scale of 0 to 10). Figure 3 shows a significant improvement in Test 2 with a $7.5 \%$ increase in the maximum care strip.

On the question on everyday consumption habits (food, clothing, climate change, 26.3\% indicated in Test 1 that they believed that they had a little influence (indications 0 to 4 on the scale of 0 to 10 ); $15.8 \%$ agreed that it greatly influenced them (indications 8 to 10 on the scale of o to 10), while $57.9 \%$ were on the acceptable scale (indications 5 to 7 on the scale of 0 to 10). Test 2 results showed that $18.9 \%$ indicated that consumption habits had little influence (indications $\mathrm{O}$ to 4 on the scale of $\mathrm{O}$ to 10 ); $22.9 \%$ admitted that these habits had a significant influence (indications 8 to 10 on the scale from 0 to 10 ), with $58.2 \%$ on the acceptable scale (indications 5 to 7 on the scale of 0 to 10 ). A slight improvement was observed in Test 2 with an increase of $7.1 \%$ in the maximum influence strip.

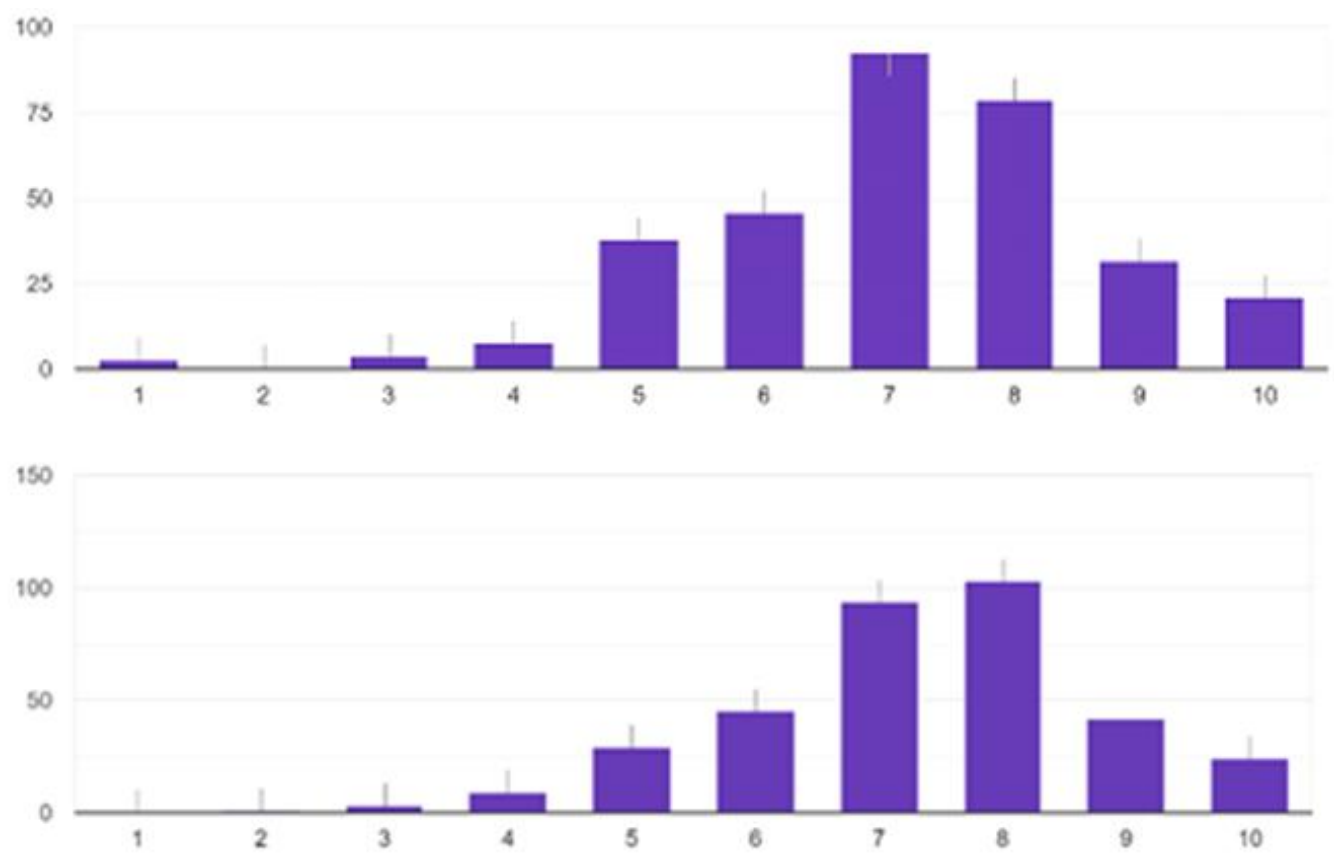

Figure 3. Proactive questions. Relative percentage improvement in Test 2. Do you take care of the environment?. 
On the question whether you would like to participate in an environmental project or activity, $14.2 \%$ respondents in Test 1 said a little or to some extent (indications 0 to 4 on the scale from 0 to 10 ) while $50 \%$ said they would participate a lot (indications 8 to 10 on the scale from 0 to 10 ), and $35.8 \%$ were found acceptable (indications 5 to 7 on the scale of 0 to 10 ). In Test $2,17,7 \%$ admitted to participate a little (indications 0 to 4 on the scale from 0 to 10 ) and $41.3 \%$ said to participate too much (indications 8 to 10 on the scale from 0 to 10 ), placing the acceptable scale at $41 \%$ (indications 5 to 7 on the scale of 0 to 10). A worsening result in Test 2 was observed with a decrease of $8.7 \%$ in the maximum influence strip.

The answers to the most personal questions were significantly positive in Test 2 , however it highlighted a worsening of the range of maximum interest in participating in environmental projects. The most procedural questions were 4, 8.9 and 11 . The first three were related to recycling and reducing environmental impact. On the choice of container for recycling, $81.1 \%$ voted for metal/plastic containers while $85.7 \%$ opted this choice in Test 2. A great success was observed in both tests with a slight improvement in Test $2(+4.6 \%)$.

On the reduction of environmental impact, $84.6 \%$ in Test 1 and $89.9 \%$ in Test 2 voted in agreement. A great success was observed in both tests with a slight improvement in Test $2(+5.3 \%)$ as shown in Figure 4 . The option of electronic garbage (equipment, batteries, etc.) was chosen by $89.8 \%$ in Test 1 and $92.9 \%$ in Test 2 . A great success was observed in both tests with a slight improvement in Test $2(+3.1 \%)$. The answers to the most procedural questions had very good results in both tests. Students opted the choice of recycling as a mode of reducing the environmental impact, with slight improvements in test 2. Finally, in terms of the awareness about the project to build a green lung (Malaga urban forest) on the land near the school, 60.1\% in Test 1 and 62.3\% in Test 2 said they did not know about it, indicating that participants had little information and participation in green projects.
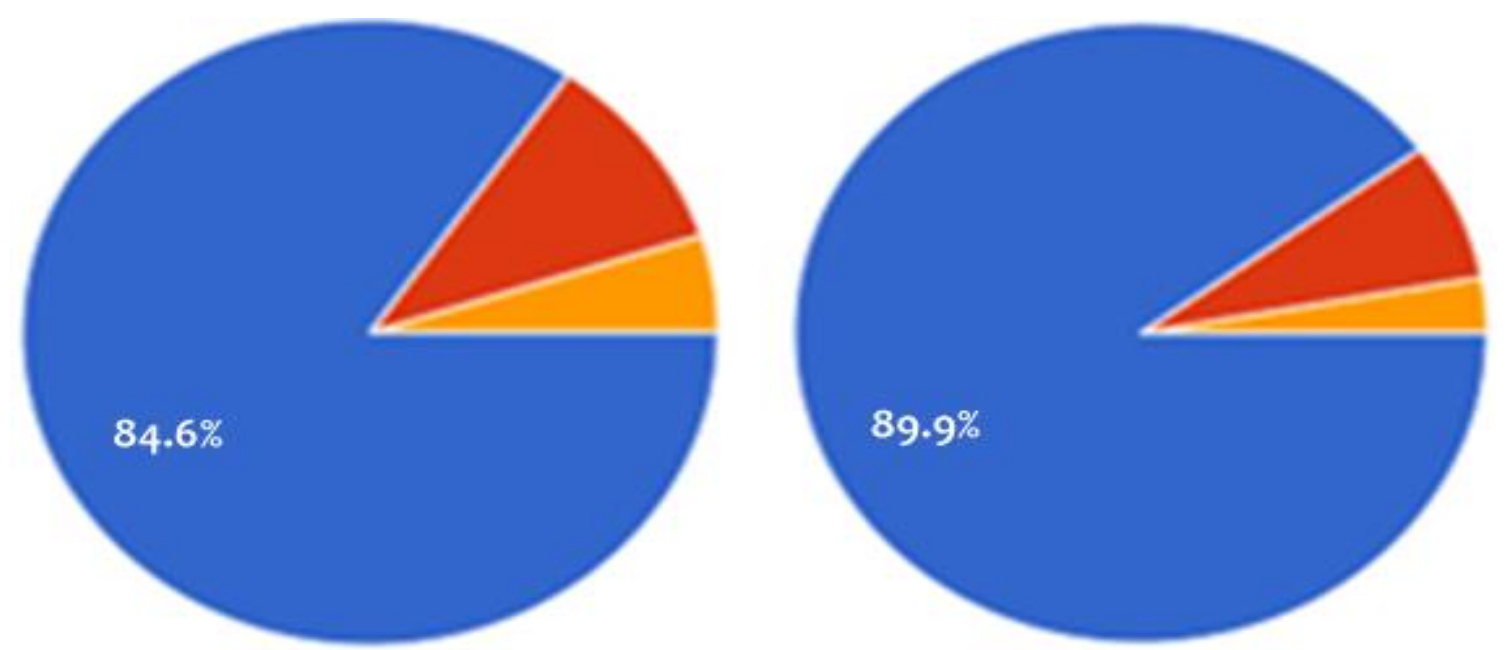

Figure 4. Procedural questions. Relative percentage improvement in Test 2.

A two-factor ANOVA method on one or more samples per group was performed on questions blocks basis to understand the variation of questions regarding the confinement situation. Table 1 presents the Two-factor ANOVA analysis of questions 2,6 and 10 .

Table 1. Two-factor ANOVA in proactive questions (2.6 and 10).

\begin{tabular}{c|c|c|c|c|c|c}
\hline Variance Analysis & & & & \\
\hline $\begin{array}{c}\text { Origin of } \\
\text { variations }\end{array}$ & Sum of squares & $\begin{array}{c}\text { Degrees of } \\
\text { freedom }\end{array}$ & $\begin{array}{c}\text { Average } \\
\text { squares }\end{array}$ & F & $\begin{array}{c}\text { Critical value } \\
\text { for F }\end{array}$ \\
\hline Sample & 0.299 & 1 & 0.299 & 0.067 & 0.796 & 3.846 \\
\hline Columns & 762.275 & 2 & 381.137 & 85.365 & 0 & 3.001 \\
\hline Interaction & 108.882 & 2 & 54.441 & 12.193 & 0.055 & 3.001 \\
\hline Within Group & 8572.467 & 1920 & 4.465 & & & \\
\hline Total & 9443.924 & 1925 & & & & \\
\hline
\end{tabular}


The first Block was defined as having more conceptual questions (e.g., 1, 3, 5 and 7). The results of ANOVA revealed significant differences between the two tests. The second Block was proactive, comprising personal questions e.g., 2, 6 and 10. It was observed that there was an interaction, as indicated in Table 1, in which the data were all numerical in groups. In addition to an improvement in questions 2 and 6 , a negative result was seen in question 10, which is coinciding with the greatest variance. The third block contained procedural questions, e.g., 4, 8.9 and 11. The first three were related to recycling and environmental impact reduction and the results showed that there were significant differences between the two tests with probabilities in ANOVA between 0.0002 and 0.013 .

\section{CONCLUSION}

The COVID-19 confinement circumstances significantly influenced the results of both the tests, conducted in 2019 and 2020. The two tests examined student' awareness about the environment, with the view to understand what opportunities could advance ESD and accomplish better results globally. The question items of these tests were verified by ANOVA and Bonferroni, in addition to making a question to question basis comparison. Conceptual aspects achieved similar results, which encourages us to focus on education for sustainable development in a more procedural and proactive field. This also resulted in a greater positive differentiation in surveys in the areas of recycling, environmental impact reduction and consumption habits, which presented very positive results.

The study results also revealed a decreased interest in participating in environmental projects, possibly due to the suspicion of going abroad in full confinement. This necessitates taking a third test in 2021. Moreover, conceptual questions regarding renewable energy showed greater diversity in Test 2, indicating even lower than expected results since the conceptual questions could derive positive results. The highest number of students participated in the third level of ESO. This level proved to be the most popularly aspect explored and focused in terms of activities. The female students generally showed greater progress in this level. An important result of this study dealt with the BUM (Urban Forest of Malaga), a project of great environmental impact in the city and in the lands near the educational center. This leads us to think about the distance between citizens and urban policy and reflect on how to bridge these gaps in the participation of students in these projects.

Funding: This study received no specific financial support.

Competing Interests: The authors declare that they have no competing interests.

Acknowledgement: Authors thank the Department of Graphic Expression in Engineering of the University of Malaga and the students of the Secondary School Miguel Romero Esteo for the support received.

\section{REFERENCES}

Annan-Diab, F., \& Molinari, C. (2017). Interdisciplinarity: Practical approach to advancing education for sustainability and for the sustainable development goals. International Journal of Management Education, 15(2), 73-83. Available at: https://doi.org/10.1016/j.ijme.2017.03.006.

Ashrafian, T., \& Moazzen, N. (2019). The impact of glazing ratio and window configuration on occupants' comfort and energy demand: The case study of a school building in Eskisehir, Turkey. Sustainable Cities and Society, 47, 101483. Available at: https://doi.org/10.1016/j.scs.2019.101483.

Azeiteiro, U. M., Bacelar-Nicolau, P., Caetano, F. J., \& Caeiro, S. (2015). Education for sustainable development through elearning in higher education: Experiences from Portugal. Journal of Cleaner Production, 106, 308-319. Available at: https://doi.org/10.1016/j.jclepro.2014.11.056.

Boeve-de Pauw, J., \& Van Petegem, P. (2018). Eco-school evaluation beyond labels: The impact of environmental policy, didactics and nature at school on student outcomes. Environmental Education Research, 24(9), 1250-1267. Available at: https://doi.org/10.1080/13504622.2017.1307327. 
Braun, T., \& Dierkes, P. (2017). Connecting students to nature-how intensity of nature experience and student age influence the success of outdoor education programs. Environmental Education Research, 23(7), 937-949. Available at: https://doi.org/10.1080/13504622.2016.1214866.

Carbach, E., \& Fischer, D. (2017). Sustainability reporting at schools: Challenges and benefits. Journal of Teacher Education for Sustainability, 19(1), 69-81. Available at: https://doi.org/10.1515/jtes-2017-0005.

Cheong, I. P.-A., Johari, M., Said, H., \& Treagust, D. F. (2015). What do you know about alternative energy? Development and use of a diagnostic instrument for upper secondary school science. International Journal of Science Education, 37(2), 210236. Available at: https://doi.org/10.1080/09500693.2014.976295.

Clark, A. (2010). Transforming children's spaces: Children's and adults' participation in designing learning environments (pp. 137-152). NY (USA): Routledge.

Cooke, S. (2010). Healthy and sustainable environments for children and communities. Young Children and the Environment: Early Education for Sustainability, 242-272. Available at: https://doi.org/10.1017/cbo9780511845390.010.

De Jager, T. (2015). A proposal to integrate the management of electronic waste into the curriculum of primary schools. Eurasia Journal of Mathematics, Science and Technology Education, 11(3), 443-454. Available at: https://doi.org/10.12973/eurasia.2015.1340a.

De Pauw, J. B., Gericke, N., Olsson, D., \& Berglund, T. (2015). The effectiveness of education for sustainable development. Sustainability, 7(11), 1-25.

Disterheft, A., Caeiro, S., Azeiteiro, U. M., \& Leal, F. W. (2013). Sustainability science and education for sustainable development in universities: A way for transition. In Sustainability assessment tools in higher education institutions (pp. 3-27). Cham: Springer.

Gaona, A. (2000). Sustainable development and solidarity development. To Communicate, 8(15), 83-91.

Gardner, A. A. (2017). Sustainability toolkit: An educational tool for behavioral change strategies. Electronic Thesis. The University of Arizona (USA).

Gönüllü, M. T., Doğan, S., \& Çelik, Z. (2015). National education. Awareness of children in primary school about the hazardous packaging material to environment (A sample of Istanbul). Milli Egitim. Turkey., 1, 44-63.

Haddad, R., \& Kalaani, Y. (2014). Google forms: A real- Time formative feedback process for adaptive learning. Paper presented at the ASEE Annual Conference and Exposition, Conference Proceedings.

Hedefalk, M., Almqvist, J., \& Östman, L. (2015). Education for sustainable development in early childhood education: A review of the research literature. Environmental Education Research, 21(7), 975-990. Available at: https://doi.org/10.1080/13504622.2014.971716.

Iyengar, K. (2015). Sustainable architectural design: An overview (pp. 30-65). NY (USA): Routledge.

Izadpanahi, P., Elkadi, H., \& Tucker, R. (2017). Greenhouse affect: The relationship between the sustainable design of schools and children's environmental attitudes. Environmental Education Research, 23(7), 901-918. Available at: https://doi.org/10.1080/13504622.2015.1072137.

Jena, A. K., Bhattacharjee, S., \& Langthasa, P. (2015). Effects of multimedia on knowledge, understanding, skills, practice and confidence in environmental sustainability: A non-equivalent pre-test-post-test, Quasi experimental design. Journal of Educational Technology, 12(3), 37-47. Available at: https://doi.org/10.26634/jet.12.3.3744.

Kane, T. E. (2011). Transforming the soul of education: Sustainability at the center of teaching and learning in secondary schools. Portland State University (USA). Dissertations and Theses. Paper 270.

Keramitsoglou, K. M. (2016). Exploring adolescents' knowledge, perceptions and attitudes towards renewable energy sources: A colour choice approach. Renewable and Sustainable Energy Reviews, 59, 1159-1169. Available at: https://doi.org/10.1016/j.rser.2015.12.047.

McCullough, M. B., Martin, M. D., \& Sajady, M. A. (2018). Implementing green walls in schools. Frontiers in Psychology, $9,619$. Available at: https://doi.org/10.3389/fpsyg.2018.00619. 
Meron, N., \& Meir, I. A. (2017). Building green schools in Israel. Costs, economic benefits and teacher satisfaction. Energy and Buildings, 154, 12-18. Available at: https://doi.org/10.1016/j.enbuild.2017.07.044.

Mirchandani, N. (2015). Existing buildings: Refurbishment, remodelling \& extension future schools (pp. 105-125). London: RIBA Publishing.

Ozburak, C., Batırbaygil, M. H., \& Uzunoglu, S. S. (2018). Sustainable environment education in pre-school pupils. Eurasia Journal of Mathematics, Science and Technology Education, 14(7), 3367-3379. Available at: https://doi.org/10.29333/ejmste/91874.

Perello-Marín, M. R., Ribes-Giner, G., \& Pantoja Díaz, O. (2018). Enhancing education for sustainable development in environmental university programmes: A co-creation approach. Sustainability, 10(1), 158. Available at: https://doi.org/10.3390/su10010158.

Pérez-Belis, V., Bovea, M. D., \& Simó, A. (2015). Consumer behaviour and environmental education in the field of waste electrical and electronic toys: A Spanish case study. Waste Management, 36, 277-288. Available at: https://doi.org/10.1016/j.wasman.2014.10.022.

Phan, H., Thu, T., \& Kato, T. (2016). Measuring the effect of environmental education for sustainable development at elementary schools: A case study in Da Nang city, Vietnam. Sustainable Environment Research, 26(6), 274-286. Available at: https://doi.org/10.1016/j.serj.2016.08.005.

Prabawani, B., Hanika, I. M., Pradhanawati, A., \& Budiatmo, A. (2017). Primary schools eco-friendly education in the frame of education for sustainable development. International Journal of Environmental and Science Education, 12(4), 607-616.

Reunamo, J., \& Suomela, L. (2013). Education for sustainable development in early childhood education in Finland. Journal of Teacher Education for Sustainability, 15(2), 91-102. Available at: https://doi.org/10.2478/jtes-2013-0014.

Rozema, A., Mathijssen, J., Jansen, M., \& Van Oers, J. (2018). Sustainability of outdoor school ground smoking bans at second ary schools: A mixed-method study. The European Journal of Public Health, 28(1), 43-49. Available at: https://doi.org/10.1093/eurpub/ckx099.

Santos, D. V. W. C., Singh, D., Delgado Leandro da Cruz, L., De Carvalho Piassi, L. P., \& Reis, G. (2019). Vertical gardens: Sustainability, youth participation, and the promotion of change in a socio-economically vulnerable community in Brazil. Education Sciences, 9(3), 161. Available at: https://doi.org/10.3390/educsci9030161.

Saraiva, T. S., Almeida, M., Bragança, L., \& Barbosa, M. T. (2019). The inclusion of a sustainability awareness indicator in assessment tools for high school buildings. Sustainability, 11(2), 387. Available at: https://doi.org/10.3390/su1 1020387.

Tucker, R., \& Izadpanahi, P. (2017). Live green, think green: Sustainable school architecture and children's environmental attitudes and behaviors. Journal of Environmental Psychology, 51, 209-216. Available at: https://doi.org/10.1016/j.jenvp.2017.04.003.

UNESCO. (2018). Issues and trends in education for sustainable development (pp. 133-136). United Nations Educational, Scientific and Cultural Organization. Paris (France).

United Nations. (2018). The sustainable development goals report (pp. 5-13). United Nations Sustainable Development.

Verhulst, E., \& Lambrechts, W. (2015). Fostering the incorporation of sustainable development in higher education. Lessons learned from a change management perspective. Journal of Cleaner Production, 106, 189-204. Available at: https://doi.org/10.1016/j.jclepro.2014.09.049.

Wals, A. E. J. (2012). Shaping the education of tomorrow (pp. 18-55). United Nations Educational, Scientific and Cultural Organization. Paris (France).

Willis, K. (2018). The sustainable development goals. In The Routledge Handbook of Latin American Development (pp. 121131). USA: Routledge.

Views and opinions expressed in this article are the views and opinions of the author(s), International Journal of Education and Practice shall not be responsible or answerable for any loss, damage or liability etc. caused in relation to/arising out of the use of the content. 